\title{
A INSTITUIÇÃO DE FERIADOS RELIGIOSOS NO ESTADO DEMOCRÁTICO DE DIREITO BRASILEIRO: uma discussão à luz do princípio da laicidade estatal
}

\author{
Stéphanie Nathanael Lemos ${ }^{1}$ \\ Márcio Eduardo Senra Nogueira Pedrosa Morais²
}

\section{Resumo}

A influência histórica da religiosidade no cotidiano da sociedade brasileira é percebida sob vários aspectos, dentre eles, na definição de feriados nacionais de cunho religioso no calendário oficial. Embora o Brasil seja constitucionalmente um país laico, os feriados nacionais devem ser respeitados por todos os cidadãos, repercutindo em todos os segmentos da sociedade, tanto no público, quanto no privado. Nesse contexto, em face da laicidade do Estado e do direto fundamental à liberdade religiosa, insere o presente trabalho, que tem por objetivo analisar o arcabouço jurídico que respalda a instituição de feriados religiosos no país.

Palavras-chave: Liberdade religiosa. Feriados religiosos. Laicidade. Igualdade. Princípio democrático.

\section{THE INSTITUTION OF RELIGIOUS HOLIDAYS IN THE BRAZILIAN DEMOCRATIC STATE OF LAW: a discussion in light of the principle of state laicity}

\begin{abstract}
The influence of religiosity on the daily life of Brazilian society is noticed in several aspects, among them, in the definition of national holidays of a religious nature in the official calendar. Although Brazil is constitutionally a secular state, national holidays must be respected by all citizens, impacting on all segments of society, both publicly and privately. In this context, in view of the laity of the state and the fundamental right to religious liberty, this work inserts this work, which aims to analyze the legal framework that supports the institution of religious holidays in the state.

\footnotetext{
${ }^{1}$ Especialista em Gestão Pública Municipal (UFU). Mestranda no Programa de pós-graduação Stricto Sensu da Universidade de Itaúna. Advogada. Docente na Universidade de Patos de Minas. Endereço residencial: Rua Tobias Cândido, n. ${ }^{0} 177$ - apartamento 208 - Centro - PATOS DE MINAS/MG - CEP 38700120 - Email: stephanielemosadv@yahoo.com.br.

2 Doutor e Mestre em Teoria do Direito pela Pucminas. Professor da graduação e do Programa de Pós-graduação Stricto Sensu em Direito da Universidade de Itaúna. Professor da Faculdade de Pará de Minas-MG. Endereço residencial: Rua Raimundo de Almeida, n. 394 - apartamento 301 - Bairro Nova Vila Mozart - ITAÚNA/MG CEP 35680-183. Email: marcioeduardopedrosamorais@gmail.com
}

Revista Brasileira de Direitos e Garantias Fundamentais | e-ISSN: 2526-0111 | Maranhão | v. 3 | n. 2 | p. $20-41$ | Jul/Dez. 2017. 
Keywords: Religious freedom. Religious holidays. Laicity. Equality. Democratic principle.

\section{INTRODUÇÃO}

O Brasil, devido à sua colonização portuguesa, é um país com raízes religiosas, sobretudo de origem católica. Durante o seu período colonial houve também sua colonização espiritual, com a chegada de ordens religiosas católicas objetivando a instituição de uma estrutura cultural e social amparada no catolicismo, a religião portuguesa trazida d'além mar.

Após a sua emancipação (1822) até a proclamação da República, ocorrida em 1891, por força da Constituição monárquica de 1824, o país permaneceu como um Estado confessional católico. Posteriormente, todas as constituições reafirmaram a separação do poder estatal da religião, de forma que, hoje, a liberdade religiosa é consagrada no texto da Constituição da República Federativa do Brasil de 1988 (CRFB/88) como direito fundamental, tendo o Estado brasileiro adotado a forma de Estado laico.

Estruturalmente, a laicidade é princípio do qual decorrem os seguintes princípios: i) o princípio da liberdade religiosa; ii) o princípio da igualdade; e iii) o princípio democrático.

A despeito da laicidade do Estado brasileiro, a dimensão objetiva do princípio da liberdade religiosa exige do Estado uma posição de neutralidade quanto às manifestações sociais religiosas, assegurando a liberdade de se confessar ou não uma fé ou uma ideologia. Proteger o indivíduo contra perturbações ou qualquer tipo de coação oriunda do Estado ou de particulares é pressuposto dos postulados do Estado Democrático de Direito.

Perpassando essa problemática está a questão dos feriados religiosos no Estado Democrático laico. No Brasil, a incorporação desses feriados ao calendário oficial do Estado, de acordo com o artigo $8^{\circ}$ da Lei n. ${ }^{0} 605$ de 5 de janeiro $1949^{3}$, implica na vedação ao trabalho por parte de todos os subordinados à soberania estatal.

\footnotetext{
${ }^{3}$ Art. $8^{\circ}$ Excetuados os casos em que a execução do serviço for imposta pelas exigências técnicas das empresas, é vedado o trabalho em dias feriados, civis e religiosos, garantida, entretanto, aos empregados a remuneração respectiva, observados os dispositivos dos artigos $6^{\circ}$ e $7^{\circ}$ desta lei (BRASIL, 2017c).
} 
Deste modo, o problema que se apresenta consiste na investigação do papel do Estado laico no processo de livre manifestação da liberdade religiosa e preservação dos princípios democráticos. Nesse cenário de aparente conflito, surgem alguns questionamentos, tais como: pode um Estado laico fixar em seu calendário oficial feriados religiosos? Ao não admitir a eleição de feriados religiosos, estaria o Estado violando a liberdade de culto garantida constitucionalmente?

O objetivo primordial deste estudo é analisar a institucionalização de feriados religiosos em face do princípio da laicidade estatal. As razões que justificam a presente pesquisa consistem nas frequentes demandas judiciais que questionam a legislação (federal, estadual e municipal) que inseriram, nos respectivos calendários, feriados religiosos, de forma a impor àqueles cidadãos que divergem de determinada crença os reflexos do culto dessa.

Estruturalmente, o trabalho se divide em 2 seções temáticas, mais introdução e conclusão. Na primeira seção, intitulada Laicidade e liberdade religiosa no Estado Constitucional brasileiro, aborda-se a relação instaurada entre religião e Estado, analisandose os desdobramentos da liberdade religiosa num Estado laico, como também a situação da liberdade religiosa na história constitucional brasileira. Na seção seguinte, com o título Os feriados religiosos no estado brasileiro: ofensa à laicidade ou manifestação cultural histórica, é analisado o arcabouço normativo federal que institui os feriados brasileiros em âmbito nacional, como também se discorre sobre a natureza dos feriados religiosos, como manifestação social histórico-cultural e sua relação com o Estado laico.

Quanto à metodologia, para a realização do estudo, utilizou-se da pesquisa teóricobibliográfica, tendo em vista que a construção do debate teórico se embasa, de maneira considerável, em doutrina em relação à temática proposta. No que tange ao procedimento metodológico, optou-se pelo método dedutivo, haja vista partir-se de uma concepção macro para uma concepção microanalítica, permitindo-se, portanto, a delimitação do problema teórico. Finalmente, no procedimento técnico, foram adotadas as análises interpretativas, comparativas, históricas e temáticas, possibilitando uma discussão pautada sob o ponto de vista da crítica científica. 


\section{LAICIDADE E LIBERDADE RELIGIOSA NO ESTADO CONSTITUCIONAL} BRASILEIRO

A crença no sobrenatural remonta aos primórdios da humanidade, sendo possível perceber, atualmente, a influência da religiosidade na sociedade humana em vários aspectos, desde ritos que celebram o nascimento, à influência na construção da moral social e da política na história de suas relações institucionais com o Estado, até a eleição de feriados no calendário oficial. ${ }^{4}$

Para a compreensão do princípio da liberdade religiosa no Estado Democrático brasileiro, faz-se necessário conceituar o Estado laico, bem como ponderar sua dimensão, diferenciando-o do Estado laicista. Também se faz importante analisar, mesmo que brevemente, o espaço constitucional dado à religiosidade nas constituições brasileiras.

Nesse sentido, a relação entre Estado e Religião pode ser analisada em decorrência de sua proximidade ou repulsa, sendo classificada como de cunho confessional, quando um sistema de governo une religião e política. De forma oposta, se o Estado hostiliza a influência social ou política do mundo clerical, a relação é denominada de anticlerical. Existe ainda uma relação de neutralidade, denominada de laicidade, que ocorre quando o Estado assume um distanciamento entre as relações religiosas e políticas.

\footnotetext{
4 "As liberdades de consciência, de crença e de culto, as duas últimas usualmente abrangidas pela expressão genérica "liberdade religiosa", constituem uma das mais antigas e fortes reivindicações do indivíduo. Levando em conta o seu caráter sensível (de vez que associado à espiritualidade humana) e mesmo à sua exploração política, sem falar nas perseguições, e mesmo atrocidades, cometidas em nome da religião e por conta da amplamente praticada intolerância religiosa ao longo dos tempos, foi uma das primeiras liberdades asseguradas nas declarações de direitos, e uma das primeiras, também, a alcançar a condição de direito humano e fundamental consagrado na esfera do direito internacional dos direitos humanos e nos catálogos constitucionais de direitos. Georg Jellinek, em importante estudo sobre a origem da Declaração dos Direitos do Homem e do Cidadão (1789), sustentou que a liberdade religiosa, especialmente tal como reconhecida nas declarações de direitos das ex-colônias inglesas na América do Norte, foi a primeira expressão da ideia de um direito universal e fundamental da pessoa humana. Independentemente da posição de Jellinek estar, ou não, correta em toda sua extensão, o fato é que a proteção das opiniões e cultos de expressão religiosa, que guarda direta relação com a espiritualidade e o modo de conduzir a vida dos indivíduos e mesmo de comunidades inteiras, sempre esteve na pauta preferencial das agendas nacionais e supranacionais em matéria de direitos humanos e fundamentais, assim como ocorre na esfera do direito constitucional positivo brasileiro" (SARLET, 2015).
} 
Didaticamente, Jorge Miranda ${ }^{5}$ apresenta um painel acerca das relações entre Estado e Religião, apresentando-se como gêneros: i) Identificação entre Estado e religião, entre comunidade política e comunidade religiosa (Estado confessional $^{6}$ ); ii) Não identificação (Estado laico); e iii) Oposição do Estado à religião. No primeiro tipo de relação, a identificação entre Estado e religião, que caracteriza o Estado como Estado confessional, suas duas espécies são: a) teocracia7 , ou seja, o sistema de identificação com domínio do poder religioso sobre o poder político; e b) cesaropapismo, sistema com domínio do poder político sobre o poder religioso.

No estado laico, as instituições Igreja e Estado, no que se refere aos seus poderes e atribuições, não se confundem. Para Daniel Sarmento, “a laicidade caracteriza-se como uma verdadeira garantia institucional da liberdade religiosa individual”, ${ }^{8}$ pois a laicidade protege o Estado de possíveis influências religiosas, impedindo confusão entre o poder exercido pela igreja e o poder democrático exercido por autoridades públicas.

A posição de laicidade de um Estado não significa a adoção de uma religiosidade ateísta, que nega a existência de Deus, mas tão somente que o Estado assume uma posição de neutralidade quanto às diferentes concepções religiosas presentes na sociedade, sendo-lhe vedado favorecimento ou embaraço de qualquer cresça. Nesse sentido, reforça Sarmento ser

\footnotetext{
${ }^{5}$ MIRANDA, Jorge. Estado, liberdade religiosa e laicidade. In: MARTINS FILHO, Ives Gandra da Silva; NOBRE, Milton Augusto de Brito (Org.) O estado laico e a liberdade religiosa. São Paulo: LTr, 2011, pp. 106124.

${ }^{6} \mathrm{O}$ Estado confessional possui três particularidades básicas: primeiramente o Estado professa, do mesmo modo que os indivíduos, uma religião determinada; a garantia dos adeptos da religião do Estado à liberdade eclesiástica, dentro dos limites fixados pela jurisdição originária e soberana sobre os assuntos espirituais; a concessão aos adeptos de religiões diferentes da religião do Estado de um regime de "tolerância", cuja amplitude e persistência varia segundo conveniência. Assim, no Estado confessional não há nem igual liberdade de consciência nem igual liberdade em matéria religiosa. (CHIASSONI, 2013).

${ }^{7}$ Para Pierluigi Chiassoni (2013) o Estado teocrático se caracteriza pela confusão entre hierarquia estatal e hierarquia eclesiástica, sendo o chefe religioso, ao mesmo tempo, chefe de Estado. Não havendo espaço para liberdade de consciência, tampouco para liberdade em matéria de religião.

${ }^{8}$ SARMENTO, Daniel. O Crucifixo nos Tribunais e a Laicidade do Estado. Revista Eletrônica Prpe, Recife, maio 2007. Disponível em: <http://www.prpe.mpf.mp.br/internet/index.php/internet/Legislacao-e-RevistaEletronica/Revista-Eletronica/2007-ano-5/O-Crucifixo-nos-Tribunais-e-a-Laicidade-do-Estado>. Acesso em: 28 maio 2017.
} 
“o ateísmo, na sua negativa da existência de Deus, também uma crença religiosa, que não pode ser privilegiada pelo Estado em detrimento de qualquer outra cosmovisão”. ${ }^{9}$

Sarmento $^{10}$ pondera que o princípio do laicidade estatal pode se relacionar diretamente a dois direitos fundamentais extremamente relevantes, quais sejam: liberdade de religião e igualdade. No mesmo sentido, Cláudio Márcio Bernardes e Márcio Eduardo Senra Nogueira Pedrosa ${ }^{11}$ afirmam ser o princípio da liberdade religiosa, um direito humano positivado no texto constitucional, e, por essa razão, assume condição de direito fundamental que, juntamente com o princípio democrático e o princípio da igualdade, forma o princípio da laicidade estatal.

Em contraponto ao princípio da laicidade, a doutrina expõe o princípio laicista, ou seja, é possível teorizar o Estado laico (de matriz norte-americana) e o Estado laicista (de matriz francesa).

Segundo o magistério de Jorge Bacelar Gouveia, o Estado laicista é conceituado como aquele modelo de oposição ao fenômeno religioso, que objetiva afastar ou eliminar suas manifestações, podendo-se destacar dois graus de intensidade distintos, verificando-se uma atitude “de oposição mitigada, situação em que teremos um Estado laicista passivo; ou então essa oposição é levada até as últimas consequências, situação em que estaremos em face de um Estado laicista militante, ateu, de confessionalidade negativa”. ${ }^{12}$

Do princípio da laicidade decorre o princípio da liberdade religiosa, direito fundamental, que constitui prerrogativa individual oponível ao Estado, atuando no sentido de

\footnotetext{
${ }^{9}$ SARMENTO, Daniel. O Crucifixo nos Tribunais e a Laicidade do Estado. Revista Eletrônica Prpe, Recife, maio 2007. Disponível em: <http://www.prpe.mpf.mp.br/internet/index.php/internet/Legislacao-e-RevistaEletronica/Revista-Eletronica/2007-ano-5/O-Crucifixo-nos-Tribunais-e-a-Laicidade-do-Estado>. Acesso em: 28 maio 2017.

${ }^{10}$ SARMENTO, Daniel. O Crucifixo nos Tribunais e a Laicidade do Estado. Revista Eletrônica Prpe, Recife, maio 2007. Disponível em: <http://www.prpe.mpf.mp.br/internet/index.php/internet/Legislacao-e-RevistaEletronica/Revista-Eletronica/2007-ano-5/O-Crucifixo-nos-Tribunais-e-a-Laicidade-do-Estado>. Acesso em: 28 maio 2017.

${ }^{11}$ BERNARDES, Cláudio Márcio; PEDROSA, Márcio Eduardo Senra Nogueira. O ensino domiciliar como expressão da liberdade religiosa no estado democrático de direito. Universitas Jus, Brasília, v. 27, n. 3, 2017, pp.145-155.

${ }^{12}$ GOUVEIA, Jorge Bacelar. Direito, religião e sociedade no estado constitucional. Lisboa: IDILP, 2012, p. 120.
} 
permitir o pluralismo de crenças, como também impedindo que o indivíduo tenha a sua crença preservada (seja ela positiva ou negativa).

Nessa relação, há uma divisão incisiva entre Estado e Igreja, de modo que no respectivo território não há religião oficial, permanecendo o Estado neutro quanto às práticas religiosas. Deve ainda o Estado laico abster-se de interferir nas orientações ou preferências religiosas da sociedade, restringindo sua atuação apenas à promoção da compreensão religiosa, afastando a intolerância e o fanatismo, protegendo e garantindo o livre exercício de todas as religiões. Nessa última perspectiva, ao garantir o livre exercício de todas as religiões, o Estado promove o princípio da igualdade e o princípio democrático.

\subsection{Categorização estrutural do princípio da liberdade religiosa}

De acordo com Morais, ${ }^{13}$ a liberdade religiosa é gênero, do qual se desdobram as seguintes liberdades: i) liberdade de consciência, ii) de crença, iii) de culto e iv) de organização. Nesse sentido, a liberdade de crença garante ao sujeito o direito de escolher entre qualquer religião, qualquer crença. A liberdade de culto representa a exteriorização popular da liberdade de crença, a manifestação física mediante rito ou solenidade. A liberdade de organização, por sua vez, refere-se à possibilidade de estabelecimento e organização de igrejas e suas relações com o Estado.

No mesmo sentido, Ingo Wolfgang Sarlet, ao definir a liberdade religiosa como direito subjetivo, afirma desdobrar-se ela em liberdades de consciência, de crença e de culto, sendo as últimas usualmente abrangidas pela expressão genérica “liberdade religiosa”. Assim:

Em uma liberdade de crença, que diz com a faculdade individual de optar por uma religião ou de mudar de religião ou de crença, ao passo que a liberdade de culto, que guarda relação com a exteriorização da crença, diz com os ritos, cerimônias, locais e outros aspectos essenciais ao exercício da liberdade de religião e de crença. Também a liberdade de associação e de organização religiosa encontra-se incluída no âmbito de proteção da liberdade religiosa, de tal sorte que ao Estado é vedado, em princípio, interferir na esfera interna das associações religiosas. ${ }^{14}$

\footnotetext{
13 MORAIS, Márcio Eduardo Pedrosa. Liberdade religiosa: o ensino religioso na Assembleia Nacional Constituinte de 1987-1988. Curitiba: Juruá, 2015.

14 SARLET, Ingo Wolfgang. Algumas notas sobre a liberdade religiosa na Constituição Federal de 1988.

Doutrinas Essenciais de Direito Constitucional, São Paulo, v. 8, pp. 829-845, ago. 2015.
} 
A liberdade religiosa e suas ramificações possuem dupla dimensão de eficácia, uma subjetiva e outra objetiva. Enquanto direitos subjetivos, elas "asseguram tanto a liberdade de confessar (ou não) uma fé ou ideologia, quanto geram direitos à proteção contra perturbações ou qualquer tipo de coação oriunda do Estado ou de particulares”. Numa perspectiva objetiva, "tais liberdades fundamentam a neutralidade religiosa e ideológica do Estado, como pressuposto de um processo político livre e como base do Estado Democrático de Direito”. ${ }^{15}$

Afirma ainda Sarlet, ${ }^{16}$ decorrer dessa dupla dimensão de eficácia subjetiva e objetiva tanto direitos subjetivos, quanto princípios, deveres de proteção e garantias institucionais que guardam relação com a dimensão objetiva. Ressalta também que, especificamente quanto à neutralidade religiosa e ideológica do Estado, estas se constituem elemento central das ordens constitucionais contemporâneas, especialmente no tocante ao aspecto religioso.

Ao considerar o dever de neutralidade religiosa e ideológica do Estado, decorrente da dimensão objetiva como pressuposto de um Estado Democrático, especialmente quanto à proposta apresentada na seção introdutória, qual seja, a análise da pertinência da criação e manutenção de feriados de cunho religioso no calendário oficial do Estado, merece maior detalhamento a análise da liberdade religiosa, nas suas espécies: liberdade de consciência, de crença, de culto e de organização.

Nessa perspectiva, se a liberdade de culto consiste em externalização de crença, fixar determinados dias como feriados santos no calendário oficial do Estado caracteriza-se como externalização de crença de determinada parcela da sociedade.

Apresentada a caracterização do princípio da liberdade religiosa, analisar-se-á, de forma breve, nas seções subsequentes, a evolução histórica constitucional do Estado laico brasileiro, relacionando-o com sua vertente liberdade religiosa.

\subsection{Estado laico e liberdade religiosa na história constitucional brasileira}

15 SARLET, Ingo Wolfgang. Algumas notas sobre a liberdade religiosa na Constituição Federal de 1988. Doutrinas Essenciais de Direito Constitucional, São Paulo, v. 8, pp. 829-845, ago. 2015.

16 SARLET, Ingo Wolfgang. Algumas notas sobre a liberdade religiosa na Constituição Federal de 1988.

Doutrinas Essenciais de Direito Constitucional, São Paulo, v. 8, pp.829-845, ago. 2015. 
O Estado brasileiro, assim como as constituições modernas dos Estados democráticos, prevê em seu texto, como um direito fundamental, a garantia da liberdade religiosa, de forma que, para garanti-la, se cria uma cisão constitucional entre o poder político e religião. No entanto, por um longo período (1822-1890), o Estado brasileiro experimentou a mescla entre religião e poder, assumindo, naquele tempo, o catolicismo como religião oficial.

Conforme ressalta Morais, ${ }^{17}$ no que se refere à relação religião-Estado no Brasil, pode-se dividir tal relação em duas fases: a fase confessional e a fase laica. Durante o período colonial brasileiro, a monarquia portuguesa possuía diversos mecanismos de controle da igreja, em decorrência do instituto do Padroado ${ }^{18}$ e do fato de se atribuir a ele o título de grãomestre de importantes ordens militares e religiosas de Portugal.

O Padroado foi durante todo o período colonial e imperial o sustentáculo da relação Estado-religião no Brasil, estando a Igreja a serviço do Estado (no primeiro momento, do Estado português, no segundo momento, a serviço do Estado brasileiro, após sua independência, ocorrida em 7 de setembro de 1822). ${ }^{19}$

Durante o Império brasileiro (1822-1889), com a fusão entre Igreja e Estado, vigorou o sistema confessional. ${ }^{20}$ Mesmo após a proclamação da Independência do Brasil, em 1822, no que tange à liberdade religiosa, a situação não avançou muito, de forma que a Constituição Imperial de 1824, que instituiu o catolicismo como religião oficial do Império, ${ }^{21}$ permitia

\footnotetext{
${ }^{17}$ MORAIS, Márcio Eduardo Pedrosa. Religião e direitos fundamentais: o princípio da liberdade religiosa no estado constitucional democrático brasileiro. Revista Brasileira de Direito Constitucional - RBDC, São Paulo, n. 18, jul/dez. 2011, pp. 225-242.

${ }^{18}$ No regime do padroado, como o próprio nome indica, o soberano português era o patrono da Igreja. Estabelecia-se entre o Estado e a Igreja uma estrutura jurídica semi-contratual (bilateral e onerosa) pela qual aquele recebia e cobrava diretamente da população os dízimos e rendas eclesiásticas e, em troca, obrigava-se a manter e expandir a propriedade da Igreja, financiar o esforço educacional e missionário, sustentar o clero secular (diocesano) e regular (ordens). Dentre os poderes do soberano, era significativo o advindo da designação de bispos - submetidos à aprovação papal -, párocos e outros funcionários da Igreja, que eram funcionários públicos. (ALVES, 2008, pp. 44-45).

${ }^{19}$ MORAIS, Márcio Eduardo Pedrosa. Religião e direitos fundamentais: o princípio da liberdade religiosa no estado constitucional democrático brasileiro. Revista Brasileira de Direito Constitucional - RBDC, São Paulo, n. 18, jul/dez. 2011, pp. 225-242.

${ }^{20}$ Apesar da institucionalização da Igreja Católica como religião oficial do Império, o catolicismo teve de conviver com outras religiões durante esse momento, religiões que lhe faziam concorrência: cultos africanos, o espiritismo incipiente, o protestantismo emergente.

${ }^{21}$ A religião católica foi institucionalizada no país no art. $5^{\circ}$ da Constituição Política do Império do Brasil, de 1824, nos exatos termos: “Art. 5. A Religião Católica Apostólica Romana continuará a ser a Religião do
} 
somente certa tolerância religiosa, ao passo que as demais religiões eram permitidas apenas em culto doméstico, ou particular, não podendo haver qualquer forma de manifestação fora do templo destinado a isso.

A liberdade religiosa somente é estabelecida oficialmente no ano de 1890, por intermédio do Decreto n. ${ }^{\circ}$ 119-A, de 7 de janeiro de 1890, que proibiu a intervenção da autoridade federal e dos Estados federados em matéria religiosa, consagrando a plena liberdade de cultos, como também extinguindo o Padroado. ${ }^{22}$ A Proclamação da República, no ano de 1889, foi fator decisivo para a mudança de tratamento, pelo Estado, para com a questão religiosa. A promulgação do referido decreto, nessa ótica, foi fundamental na modificação da relação entre religião e Estado. Assim, o Estado brasileiro passou de confessional a laico, antes mesmo da primeira Constituição Republicana de 1891. ${ }^{23}$

Com o objetivo de organizar um regime livre e democrático, a Constituição Republicana de 1891 previa, em seu artigo 72,24 a separação entre Estado e Igreja, almejando a instituição de um modelo de Estado laico. Deste modo, permitindo, a todos os indivíduos, o exercício público e livre de culto, foi estruturada a salvaguarda da liberdade religiosa como direito individual, ao mesmo tempo em que propunha a igualdade constitucional das religiões.

As constituições subsequentes (1934, 1937, 1946 e 1967) mantiveram o princípio da laicidade estatal, garantido a liberdade religiosa no Estado brasileiro até se chegar à atual Constituição, promulgada em 5 de outubro de 1988. Para melhor compreensão da proteção constitucional dada pela Constituição de 1988, é conveniente trazer alguns dispositivos

Império. Todas as outras Religiões serão permitidas com seu culto domestico, ou particular em casas para isso destinadas, sem forma alguma exterior de Templo” (BRASIL, 2017a).

${ }^{22}$ Previa o artigo $1^{\circ}$ do Decreto 119-A: “Art. $1^{\circ}$ É proibido à autoridade federal, assim como à dos Estados federados, expedir leis, regulamentos, ou atos administrativos, estabelecendo alguma religião, ou vedando-a, e criar diferenças entre os habitantes do país, ou nos serviços sustentados à custa do orçamento, por motivo de crenças, ou opiniões filosóficas ou religiosas”. (BRASIL, 2017h).

23 BRASIL. Constituição (1891) Constituição da república dos estados unidos do Brasil. Disponível em: <http://www.planalto.gov.br/ccivil_03/constituicao/constituicao91.htm>. Acesso em: 30 maio 2017b.

${ }^{24}$ Art. 72. A Constituição assegura a brasileiros e a estrangeiros residentes no País a inviolabilidade dos direitos concernentes à liberdade, à segurança individual e à propriedade, nos termos seguintes: [...] $\S 7^{\circ}$ - Nenhum culto ou igreja gozará de subvenção oficial, nem terá relações de dependência ou aliança com o Governo da União ou dos Estados. (BRASIL, 2017b). 
distribuídos ao longo de seu texto que estão intrinsecamente relacionados com o direito de liberdade religiosa.

O artigo $5^{\circ}$ da Constituição de 1988, em seus incisos VI, VII e VIII ${ }^{25}$, reconhece o direito à liberdade de religião como um direito fundamental de aspecto individual. O inciso VI buscou a proteção do aspecto interno (liberdade de crença) e externo (garantia do livre exercício dos cultos e liturgias, além da proteção aos locais respectivos) da liberdade de religião. Já o inciso VII assegura a assistência religiosa no caso das internações coletivas. O inciso VIII, por sua vez, impede o Estado de suprimir do cidadão, por motivo de crença religiosa, seus direitos políticos, exceto no caso de recusa à realização de obrigação a todos imposta, ou de negativa de prestação de obrigação alternativa prevista em lei.

A Constituição de 1988 também apresenta claramente sua posição de laicidade, quando afirma, no Título III - Da Organização do Estado, Capítulo I - Da Organização Político-Administrativa, artigo 19, inciso I, ser vedado à União, aos Estados, ao Distrito Federal e aos Municípios estabelecer cultos religiosos ou igrejas, subvencioná-los, embaraçar seu funcionamento ou manter com eles ou seus representantes relações de dependência ou aliança, ressalvada, na forma da lei, a colaboração de interesse público ${ }^{26}$.

Em síntese: em que pese todas as constituições republicanas brasileiras afastarem o poder estatal da religião (1891 a 1988), a concretização do Estado laico ainda é muito recente na história brasileira, ainda mais se considerado que, por aproximadamente 400 anos, permaneceu o Estado atrelado à Igreja Católica.

\footnotetext{
${ }^{25}$ Art. $5^{\circ}$ Todos são iguais perante a lei, sem distinção de qualquer natureza, garantindo-se aos brasileiros e aos estrangeiros residentes no País a inviolabilidade do direito à vida, à liberdade, à igualdade, à segurança e à propriedade, nos termos seguintes: [...] VI - é inviolável a liberdade de consciência e de crença, sendo assegurado o livre exercício dos cultos religiosos e garantida, na forma da lei, a proteção aos locais de culto e a suas liturgias; VII - é assegurada, nos termos da lei, a prestação de assistência religiosa nas entidades civis e militares de internação coletiva; VIII - ninguém será privado de direitos por motivo de crença religiosa ou de convicção filosófica ou política, salvo se as invocar para eximir-se de obrigação legal a todos imposta e recusarse a cumprir prestação alternativa, fixada em lei (BRASIL, 2017f).

${ }^{26}$ Art. 19. É vedado à União, aos Estados, ao Distrito Federal e aos Municípios:

I - estabelecer cultos religiosos ou igrejas, subvencioná-los, embaraçar-lhes o funcionamento ou manter com eles ou seus representantes relações de dependência ou aliança, ressalvada, na forma da lei, a colaboração de interesse público (BRASIL, 2017f).
} 
Na seção seguinte, analisa-se um dos reflexos decorrentes desse longo período confessional, especificamente a instituição dos feriados religiosos no Estado brasileiro e a sua análise em relação ao princípio da laicidade.

\section{OS FERIADOS RELIGIOSOS NO ESTADO BRASILEIRO: OFENSA À LAICIDADE OU MANIFESTAÇÃO CULTURAL HISTÓRICA (?)}

A instituição de feriado oficial repercute e orienta toda a sociedade, de forma que o comércio, escolas e prestação de serviços em geral são organizados conforme o calendário oficial do Estado. Dada a relevância desse calendário para a sociedade, é importante analisar o arcabouço jurídico federal que respalda a instituição de feriados no território nacional.

A Constituição de 1988 é silente quanto à fixação de feriados. Afirma apenas, no artigo 215, §2 $2^{027}$, que lei disporá sobre a fixação de datas comemorativas de alta significação para os diferentes segmentos étnicos nacionais. No âmbito infraconstitucional, existem três leis federais que definem os feriados nacionais, incluído os de caráter religioso.

A Lei $n^{0}$ 662, de 6 de abril de 1949, dispõe, sem descrever a motivação de cada data, que são feriados nacionais os dias $1^{\circ}$ de janeiro, 21 de abril, $1^{\circ}$ de maio, 7 de setembro, 2 de novembro, 15 de novembro e 25 de dezembro. Nesse rol, importante destacar que é de cunho religioso apenas o dia 2 de novembro, em comemoração ao dia de finados. Ressalta-se também que a inclusão de 2 de novembro no calendário se deu em decorrência da alteração legislativa promovida pela Lei n. ${ }^{\circ}$ 10.607, de 19 de dezembro de 2002.

A Lei $\mathrm{n}^{0}$ 6.802, de 30 de junho de $1980^{28}$, criou o feriado de 12 de outubro, que declara ser tal data feriado nacional, para culto público e oficial a Nossa Senhora Aparecida, padroeira do Brasil. A Lei $\mathrm{n}^{0}$ 9.093, 12 de setembro de 1995, dispõe sobre a institucionalização de feriados e estabelece que os feriados civis são os declarados em lei

\footnotetext{
${ }^{27}$ Art. 215. O Estado garantirá a todos o pleno exercício dos direitos culturais e acesso às fontes da cultura nacional, e apoiará e incentivará a valorização e a difusão das manifestações culturais. [...] 2 $2^{\circ}$ A lei disporá sobre a fixação de datas comemorativas de alta significação para os diferentes segmentos étnicos nacionais (BRASIL, 2017f).

${ }^{28}$ Art. $1^{\circ}$ É declarado feriado nacional o dia 12 de outubro, para culto público e oficial a Nossa Senhora Aparecida, Padroeira do Brasil (BRASIL, 2017e).
} 
federal. A mesma lei, no seu artigo $2^{\circ}$, define que "são feriados religiosos os dias de guarda, declarados em lei municipal, de acordo com a tradição local e em número não superior a quatro, neste incluída a Sexta-Feira da Paixão”. ${ }^{29}$

Obedecendo a determinação legal mencionada (artigo $1^{\circ}$, inciso I), ao final de cada ano, o Ministério do Planejamento, Desenvolvimento e Gestão divulga, por meio de portaria $^{30}$, as datas dos feriados nacionais do ano subsequente, datas essas que deverão ser observadas pelos órgãos e entidades da Administração Pública Federal direta, autárquica e fundacional do Poder Executivo. Observe-se a necessidade anual de divulgação das datas dos feriados, principalmente em decorrência da mobilidade de alguns feriados religiosos, que obedecem a cronologia de respectivos calendários.

Nesse ínterim, destacam-se os feriados oficiais de cunho religioso, a saber, de cultos católicos, e a legislação que os regulamentou. São eles: a) o dia 12 de outubro, consagrado a Nossa Senhora Aparecida, Padroeira do Brasil, conforme a Lei Federal de n. ${ }^{\circ}$ 6.802/1980; b) o dia 2 de novembro, em homenagens aos mortos, instituído na Lei Federal de n. ${ }^{\circ}$ 662/1949, com redação dada pela Lei n. ${ }^{\circ}$ 10.607, de 19 de dezembro de 2002; e c) o dia 25 de dezembro, em celebração ao nascimento de Jesus Cristo, consoante a Lei Federal de n. ${ }^{\circ}$ 662/1949.

A despeito da aparente inconstitucionalidade de se instituírem feriados religiosos num Estado laico, Joana Zylbersztajn ${ }^{31}$ chama a atenção para o reconhecimento legal de datas eminentemente religiosas, como o feriado nacional de Natal, desde 1949, e a inclusão do dia dos finados na relação, a partir de 2012, que, apesar proximidade da origem histórica nas religiões, ganharam espaço no calendário oficial em momento muito longínquo. Zylbersztajn destaca ainda a lei de 1980, que cria o feriado de Nossa Senhora de Aparecida. Sobre esse último feriado, enfatiza:

\footnotetext{
${ }^{29}$ Art. $1^{\circ}$ São feriados civis: I - os declarados em lei federal; [...] Art. $2^{\circ}$ São feriados religiosos os dias de guarda, declarados em lei municipal, de acordo com a tradição local e em número não superior a quatro, neste incluída a Sexta-Feira da Paixão (BRASIL, 2017g).

${ }^{30}$ BRASIL. Portaria n. ${ }^{\circ}$ 369, de 29 de novembro de 2016. Divulga os dias de feriados nacionais e estabelece os dias de ponto facultativo no ano de 2017, para cumprimento pelos órgãos e entidades da Administração Pública federal direta, autárquica e fundacional do Poder Executivo. Disponível em: $<$ http://pesquisa.in.gov.br/imprensa/jsp/visualiza/index.jsp?jornal=1\&pagina=78\&data=30/11/2016>. Acesso em: 30 mai. 2017i.

${ }^{31}$ ZYLBERSZTAJN, Joana. O princípio da laicidade na constituição federal de 1988. 2012. 226 f. Tese (Doutorado) - Universidade de São Paulo, Programa de Pós-Graduação em Direito.
} 
Sobre esta data, outros apontamentos são essenciais. Trata-se de uma lei razoavelmente recente, promulgada por ocasião da visita do Papa João Paulo II ao Brasil, para consagrar a Basílica de Nossa Senhora. Não há que se falar, portanto, em cultura ou tradição social que justificasse o dia como feriado nacional. Mas o que realmente chama a atenção são os termos da lei, que ouso repetir: "É declarado feriado nacional o dia 12 de outubro, para culto público e oficial a Nossa Senhora Aparecida, Padroeira do Brasil”. Quer dizer, além de tornar o dia um feriado nacional, a lei prevê que o dia seja de devoção, por meio de culto público e oficial, bem como reconhece uma santa padroeira do país. ${ }^{32}$

Esses feriados de cunho religioso, como a Paixão de Cristo, o dia de Nossa Senhora Aparecida e o Natal, criados antes mesmo da promulgação da Constituição de 1988 e as constituições anteriores, que afirmavam ser o Brasil um Estado laico, fortalecem a discussão acerca da problemática.

Excepciona ao mencionado, ou seja, surgiu no ordenamento jurídico já na vigência da Constituição de 1988, apenas o feriado de Finados (instituído por uma alteração legislativa de dezembro de 2002). Em que pese a criação da maioria dos feriados de cunho religioso se dar antes da CRFB/88, tais datas foram reinseridas no ordenamento jurídico com a edição da Lei $\mathrm{n}^{\circ}$ 9.093, 12 de setembro de 1995, a qual institucionalizou todos aqueles criados na vigência de Constituições passadas.

\subsection{Os feriados religiosos como manifestação histórico-cultural do Estado e a questão da} laicidade

Peter Häberle ${ }^{33}$ destaca serem os feriados artigos-símbolo, assim como as normas que dispõem sobre a língua, o hino, as armas, a capital federal. Deste modo, os feriados criam uma "parcela de identidade cultural para o país”. ${ }^{34}$

\footnotetext{
32 ZYLBERSZTAJN, Joana. O princípio da laicidade na constituição federal de 1988. 2012. 226 f. Tese (Doutorado) - Universidade de São Paulo, Programa de Pós-Graduação em Direito.

${ }^{33}$ HÄBERLE, Peter. Constituição e cultura: o direito ao feriado como elemento de identidade cultural do estado constitucional. Rio de Janeiro: Lumen Juris, 2008.

${ }^{34}$ HÄBERLE, Peter. Constituição e cultura: o direito ao feriado como elemento de identidade cultural do estado constitucional. Rio de Janeiro: Lumen Juris, 2008.
} 
Numa análise superficial, a instituição, em Estado laico, de feriados nacionais que tenham cunho religioso, especialmente quando se referem a apenas uma religião, causa estranheza, pois, no Estado não-confessional, devem todos os Poderes ser neutros, não podendo haver privilégio ou embaraço à manifestação religiosa de nenhuma instituição afim. Nesse sentido, tendo em base os argumentos expostos, a edição pelo Poder Legislativo de lei, instituindo feriado nacional por razões religiosas, conflita diretamente com o princípio da laicidade estatal.

O feriado é uma data em que se comemora algo importante para a história de uma sociedade. Neste sentido, devem os Estados determinarem os feriados conforme as manifestações culturais e históricas de sua população.

Claudio Maraschin trata o feriado como um bem coletivo, uma marca identificadora de um determinado povo, afirmando que o "pacto possui um profundo sentido humanista, buscando assinalar a importância da proteção de elementos essenciais para a existência humana e para a convivência social, dentre os quais o feriado”. ${ }^{35}$ Nesse sentido, o Estado constitucional aberto "necessita desses elementos culturais de base que lhe deem identidade, tanto internamente - integração do povo, sentimento de pertencimento - quanto externamente - reconhecimento”. ${ }^{36}$

Em relação aos seus aspectos jurídico, social e cultural, os feriados religiosos se relacionam à tradição religiosa, apresentando “fator cultural caracterizador”, por possuírem relação com a fundação e a história do Estado Constitucional, remetendo a valores caros para uma parte significativa do povo que a compõe. ${ }^{37}$

\footnotetext{
${ }^{35}$ MARASCHIN, Claudio. O feriado como direito fundamental e elemento indispensável para o exercício da cidadania no âmbito do estado constitucional. Revista Brasileira de Direito Constitucional - RBDC, São Paulo, n. 16, jul/dez. 2010, pp. 141-159.

${ }^{36}$ MARASCHIN, Claudio. O feriado como direito fundamental e elemento indispensável para o exercício da cidadania no âmbito do estado constitucional. Revista Brasileira de Direito Constitucional - RBDC, São Paulo, n. 16, jul/dez. 2010, pp. 141-159.

${ }^{37}$ HÄBERLE, Peter. Constituição e cultura: o direito ao feriado como elemento de identidade cultural do estado constitucional. Rio de Janeiro: Lumen Juris, 2008.
} 
Nesse sentido, Maraschin, ${ }^{38}$ no mesmo sentido de Häberle, defende que, no que se refere ao Estado laico, uma teoria constitucional cultural não pode desconsiderar a existência de feriados, mesmo que alguns sejam religiosos, vez que contribuem significativamente para o fortalecimento do sentimento de comunidade, que contribuem para a criação de vínculos de pertencimento e de reconhecimento.

De forma oposta, é possível afirmar que em um contexto democrático e plural, à luz do princípio da neutralidade e fundamentado exclusivamente no interesse público e de todos os cidadãos, a institucionalização de feriados religiosos fere os postulados democráticos, tendo em vista representarem interesses e importâncias históricas de apenas determinado grupo, no caso de religiosos.

Haveria, ainda de acordo com esse argumento, a obrigatoriedade de determinados grupos sociais não relacionados à religião referente ao feriado, terem que se obrigar à vinculação ao subjetivismo do pensamento filosófico, moral ou religioso, daquele grupo relacionado ao feriado.

A designação de uma data como feriado nacional repercute em toda a sociedade, mais ainda ao se tratar de instituição de feriado com motivação religiosa em um Estado laico. Todavia, ressalvadas as objeções atinentes ao dever de neutralidade estatal, ao desequilíbrio na manutenção do princípio da isonomia e consequentemente no princípio democrático, há de se considerar, também, a relevância cultural histórica para a formação da identidade nacional.

Deste modo, a questão deve ser observada tendo como fundamento os postulados do Estado laico, observando-se também o conceito de Estado laicista. Em breve retorno aos conceitos apresentados na seção anterior, o Estado laicista é conceituado como aquele modelo de oposição ao fenômeno religioso, que objetiva afastar ou eliminar suas manifestações.

Por sua vez, o Estado laico, que é o modelo de Estado adotado pela Constituição de 1988, não visa à eliminação do fenômeno religioso, razão pela qual é possível afirmar a

\footnotetext{
${ }^{38}$ MARASCHIN, Claudio. O feriado como direito fundamental e elemento indispensável para o exercício da cidadania no âmbito do estado constitucional. Revista Brasileira de Direito Constitucional - RBDC, São Paulo, n. 16, jul/dez. 2010, pp. 141-159.
} 
possibilidade jurídica da institucionalização de feriados religiosos, sem que isso seja considerado uma ofensa aos postulados do princípio da laicidade.

Para isso, devem ser observadas algumas premissas: i) o feriado deve constituir valor histórico para a sociedade, ultrapassando a categoria religiosa. Nesse sentido, a data a ser definida como feriado deve representar valor cultural para essa sociedade; ii) em caso de definição de feriados de cunho religioso, a população deve ser consultada por intermédio de instrumentos de democracia direta previstos no seu ordenamento jurídico. No caso brasileiro, seria fundamental a realização de plebiscito e/ou referendo. Em que pese alguns argumentos relacionados a um possível alto custo financeiro para a realização dessas consultas populares, é importante destacar a possibilidade de sua realização por intermédio da internet, por exemplo. Essas estratégias harmonizam o direito de manifestação religiosa com a participação popular de uma sociedade, auxiliando, sobremaneira, no desenvolvimento de uma maturidade cívica e democrática de um povo.

O Estado laico não pode, nem inserir o fenômeno religioso dentro das estruturas do Estado, nem afastar o fenômeno religioso, como aspecto cultural de um povo, da realidade do Estado. Assim, é fundamental não confundir o Estado laico (modelo norte-americano, adotado pela Constituição brasileira de 1988) do Estado laicista (modelo francês), de impedimento, perseguição à religião e às suas manifestações.

\section{CONCLUSÃO}

O Brasil é inegavelmente um país laico, ou seja, um Estado em que Igreja e Estado não se confundem, mantendo este uma posição de neutralidade quanto às manifestações religiosas de seu povo, conforme previsão constitucional.

Assim, corroborando para a manutenção do Estado Democrático de Direito, o princípio do laicidade estatal está diretamente relacionado a três liberdades fundamentais, quais sejam, a liberdade de religião, a democracia e a igualdade. Em síntese, o princípio da laicidade estatal é constituído pelos princípios da liberdade religiosa, da igualdade e democrático. 
No ordenamento jurídico brasileiro existem quatro feriados nacionais, indiscutivelmente de cunho religioso, instituídos em legislação federal. A leis n. ${ }^{\circ} 662$ de 1949 e 6.802 de 1980, criaram, respectivamente, os feriados de 25 de dezembro, em celebração ao nascimento de Jesus Cristo, e 12 de outubro, consagrado a Nossa Senhora Aparecida, Padroeira do Brasil. Em 1995, foi editada Lei n. ${ }^{\circ}$ 9.093, inserindo no ordenamento jurídico o feriado da Sexta-feira da Paixão, permitindo ainda que os municípios criassem outros, conforme tradição local. Em 2002, a Lei n. ${ }^{\circ}$ 10.607, modificou a redação da Lei n. ${ }^{\circ} 662$ de 1949, para incluir naquele rol o feriado de 2 de novembro, em homenagens aos mortos.

Respondendo às questões expostas na introdução da pesquisa, quais sejam: i) pode um Estado laico fixar em seu calendário oficial feriados religiosos? ii) ao não admitir a eleição de feriados religiosos, estaria o Estado violando a liberdade de culto garantida constitucionalmente (?), tem-se as conclusões a seguir apresentadas.

Em relação à possibilidade de o Estado laico fixar feriados religiosos em seu calendário oficial, tem-se que, a liberdade religiosa, na condição de direito fundamental, assegura tanto a liberdade de confessar (ou não) uma fé ou ideologia, quanto gera direito à proteção contra perturbações ou qualquer tipo de coação oriunda do Estado ou de particulares. Nessa perspectiva, a fixação de feriado nacional de ordem religiosa pelo Estado, não afronta a laicidade estatal, desde que o feriado corresponda a valores caros, fundamentais, da cultura de um povo.

Nesse sentido, esse feriado deverá ultrapassar a dimensão religiosa, caracterizando-se como elemento cultural de um povo. Não é a questão religiosa que deverá sustentar, axiologicamente, a institucionalização do feriado, mas sim aspectos culturais. Como analisado no presente estudo, laicidade difere de laicismo, e o Brasil é um Estado laico, não laicista.

Os feriados religiosos somente se harmonizam com o Estado laico caso se relacionem com valores caros para parte significativa de um povo componente do Estado Constitucional.

Em relação à segunda pergunta, qual seja, ao não admitir a eleição de feriados religiosos, estaria o Estado violando a liberdade de culto garantida constitucionalmente (?), tem-se a seguinte conclusão, relacionada essencialmente à argumentação da conclusão da 
primeira questão: caso não seja admitida a eleição de feriados religiosos que caracterizem valores culturais de um povo, essa proibição ofenderia o princípio da liberdade religiosa, especificamente sua vertente liberdade de culto.

É possível a existência de datas religiosas celebradas por mais de uma religião. Nesse sentido, caso essas datas representem valores caros a um povo, podem ser institucionalizadas como feriado.

Para essa institucionalização é fundamental que a população seja democraticamente ouvida. Procedimentalmente, seria necessária a convocação de instrumentos de democracia direta (como plebiscitos e referendos) para que a população pudesse se manifestar sobre a questão.

Em síntese, o Estado laico não afasta o fenômeno religioso de sua realidade. O que não pode ocorrer é a justificação religiosa das questões públicas. Nesse sentido, caso uma data religiosa possua representação para uma sociedade, não há nenhuma ofensa ao princípio da laicidade, sua institucionalização como feriado.

No caso brasileiro, os feriados religiosos apresentam essa característica de valores histórico-culturais de um povo, em que pese se relacionarem a religiões determinadas, o que torna possível conjugar sua institucionalização com os princípios democrático, igualitário e de liberdade religiosa, núcleos estruturantes da laicidade estatal.

\section{Referências}

ADRAGÃO, Paulo Pulido. A liberdade religiosa e o estado. Coimbra: Almedina, 2002.

ALVES, Otton Moreno de Medeiros. Liberdade religiosa institucional: direitos humanos, direito privado e espaço jurídico multicultural. Fortaleza: Fundação Konrad Adenauer, 2008.

BERNARDES, Cláudio Márcio; PEDROSA, Márcio Eduardo Senra Nogueira. O ensino domiciliar como expressão da liberdade religiosa no estado democrático de direito.

Universitas Jus, Brasília, v. 27, n. 3, 2017, pp.145-155. 
BRASIL. Constituição (1824) Constituição política do império do Brasil. Disponível em: $<$ http://www.planalto.gov.br/ccivil_03/constituicao/constituicao24.htm>. Acesso em: 30 maio 2017a.

BRASIL. Constituição (1891) Constituição da república dos estados unidos do Brasil. Disponível em: <http://www.planalto.gov.br/ccivil_03/constituicao/constituicao91.htm>. Acesso em: 30 maio 2017b.

BRASIL. Lei n. ${ }^{\mathbf{0}}$ 605, de 5 de janeiro de 1949. Repouso semanal remunerado e o pagamento de salário nos dias feriados civis e religiosos. Brasília, DF, 5 jan. 1949. Disponível em: <http://www.planalto.gov.br/ccivil_03/leis/L6802.htm>. Acesso em: 3 jun. 2017c.

BRASIL. Lei n. ${ }^{\circ}$ 662, de 6 de abril de 1949. Declara feriados nacionais os dias $1^{\circ}$ de janeiro, $1^{\circ}$ de maio, 7 de setembro, 15 de novembro e 25 de dezembro. Brasília, DF, 6 abr. 1949. Disponível em: <http://www.planalto.gov.br/ccivil_03/leis/L0662.htm>. Acesso em: 3 jun. 2017d.

BRASIL. Lei no 6.802, de 30 de junho de 1980. Declara Feriado Nacional o Dia 12 de outubro, Consagrado a Nossa Senhora Aparecida, Padroeira do Brasil. Brasília, DF, 30 jun. 1980. Disponível em: <http://www.planalto.gov.br/ccivil_03/leis/L6802.htm>. Acesso em: 2 jun. 2017e.

BRASIL. Constituição (1988) Constituição da república federativa do Brasil. Disponível em: < http://www.planalto.gov.br/ccivil_03/constituicao/constituicao.htm>. Acesso em: 30 maio 2017f.

BRASIL. Lei no 9.093, de 12 de setembro de 1995. Dispõe sobre feriados. Disponível em: <http://www.planalto.gov.br/ccivil_03/leis/19093.htm>. Acesso em: 4 jun. 2017g.

BRASIL. Decreto no 119-A, de 7 de janeiro de 1890. Disponível em: $<$ http://www.planalto.gov.br/ccivil_03/decreto/1851-1899/d119-a.htm>. Acesso em 30 maio 2017h.

BRASIL. Portaria n. ${ }^{\circ}$ 369, de 29 de novembro de 2016. Divulga os dias de feriados nacionais e estabelece os dias de ponto facultativo no ano de 2017, para cumprimento pelos órgãos e entidades da Administração Pública federal direta, autárquica e fundacional do Poder Executivo. Disponível em:

$<$ http://pesquisa.in.gov.br/imprensa/jsp/visualiza/index.jsp?jornal=1\&pagina=78\&data=30/11 /2016>. Acesso em: 30 mai. 2017i. 
CHIASSONI, Pierluigi. Laicidad y libertad religiosa. Cidade do México: UNAM, 2013.

(Coleção “Jorge Carpizo” - Para entender y pensar la laicidad).

DORNAS FILHO, João. O padroado e a igreja brasileira. São Paulo: Companhia Editora Nacional, 1938.

GOUVEIA, Jorge Bacelar. Direito, religião e sociedade no estado constitucional. Lisboa: IDILP, 2012.

HÄBERLE, Peter. Constituição e cultura: o direito ao feriado como elemento de identidade cultural do estado constitucional. Rio de Janeiro: Lumen Juris, 2008.

JELLINEK, Georg. La declaración de los derechos del hombre y del ciudadano. Cidade do México: UNAM, 2000.

MACHADO, Jónatas Eduardo Mendes. Liberdade religiosa numa comunidade constitucional inclusiva: dos direitos da verdade aos direitos dos cidadãos. Coimbra: Coimbra, 1996.

MARASCHIN, Claudio. O feriado como direito fundamental e elemento indispensável para o exercício da cidadania no âmbito do estado constitucional. Revista Brasileira de Direito Constitucional - RBDC, São Paulo, n. 16, jul/dez. 2010, pp. 141-159.

MARTINS FILHO, Ives Gandra da Silva; NOBRE, Milton Augusto de Brito (Org.) O estado laico e a liberdade religiosa. São Paulo: LTr, 2011.

MIRANDA, Jorge. Estado, liberdade religiosa e laicidade. In: MARTINS FILHO, Ives Gandra da Silva; NOBRE, Milton Augusto de Brito (Org.) O estado laico e a liberdade religiosa. São Paulo: LTr, 2011, pp. 106-124.

MORAIS, Márcio Eduardo Pedrosa. Religião e direitos fundamentais: o princípio da liberdade religiosa no estado constitucional democrático brasileiro. Revista Brasileira de Direito Constitucional - RBDC, São Paulo, n. 18, jul/dez. 2011, pp. 225-242.

MORAIS, Márcio Eduardo Pedrosa. Liberdade religiosa: o ensino religioso na Assembleia Nacional Constituinte de 1987-1988. Curitiba: Juruá, 2015. 
SARLET, Ingo Wolfgang. Algumas notas sobre a liberdade religiosa na Constituição Federal de 1988. Doutrinas Essenciais de Direito Constitucional, São Paulo, v. 8, pp.829-845, ago. 2015.

SARMENTO, Daniel. O Crucifixo nos Tribunais e a Laicidade do Estado. Revista Eletrônica Prpe, Recife, maio 2007. Disponível em:

$<$ http://www.prpe.mpf.mp.br/internet/index.php/internet/Legislacao-e-RevistaEletronica/Revista-Eletronica/2007-ano-5/O-Crucifixo-nos-Tribunais-e-a-Laicidade-doEstado>. Acesso em: 28 maio 2017.

MARTÍN-RETORTILLO, Lorenzo. Libertad religiosa y orden publico: un estudio de jurisprudencia. Madri: Tecnos, 1970.

SCAMPINI, José. A liberdade religiosa nas constituições brasileiras. Petrópolis: Vozes, 1978.

WEINGARTNER NETO, Jaime. Liberdade religiosa na constituição: fundamentalismo, pluralismo, crenças, cultos. Porto Alegre: Livraria do Advogado, 2007.

ZYLBERSZTAJN, Joana. O princípio da laicidade na constituição federal de 1988. 2012. 226 f. Tese (Doutorado) - Universidade de São Paulo, Programa de Pós-Graduação em Direito. 